\title{
Investigating Geotourism capabilities of the Gavkhoni Wetland according to the SWOT model
}

\author{
H. Beigi ${ }^{1} \&$ P. Pakzad ${ }^{2}$ \\ ${ }^{1}$ IAUN, Iran \\ ${ }^{2}$ Beheshti University, Iran
}

\begin{abstract}
Tourism and the environment are so close to each other and the physical environment creates innumerable attraction for sustainable tourism. Geotourism as a new choice in sustainable tourism not only focuses on all natural and humanistic features but also considers the performance of one place.

One can play an effective role in the national development and national economy diversification of the area by planning and recognizing the opportunities as well as the limitation of Geotourism.

Thus, there are two questions here:

1. What are the potentialities and limitations of Geotourism development?

2. Which strategies are required for developing this type of tourism and following national and regional development?

Using measurement and field studies methods and determination of the strengths, weaknesses, opportunities and threats by SWOT, the authors provide some strategies and suggestions for developing Geotourism in the Gavkhoni Wetland.

Experimental analysis about this area presents that although the geotourist in this area is very various, this area is confronted with serious transregional threats. We will have a powerful Geotourism pole in this region, if the tourism infrastructure policies minimize and review.
\end{abstract}

Keywords: Geotourism, geotourist investments, SWOT model. 


\section{Introduction}

Nowadays, sustainable tourism is a comprehensive achievement that is willing for long-lasting development of the tourism industry without destructive effects on the natural habitat (Sharifzadeh and Moradnejad [11]). Sustainable tourism considers tourism as a frontier border where a triangular relationship is established among the host society, its land and guest society or tourists in the one hand, and on the other hand among the host society, its land and tourism.

Geotourism as a new concept of tourism is based on the special geographic specification of one place, takes people's willingness all over the world ever increasingly. We can describe Geotourism as below:

"A kind of tourism that stabilizes and promotes the geographic specification of one place (it includes environment, inheritance, beautifulness, culture and welfare of the local people.)" (Tourtellot [12]).

Certainly Geotourism should be sustainable - meaning that it should not have a destructive effect. Moreover, it centralizes all of the natural and human characteristics that can become visually worthy of one place.

The aims of Geotourism are based on the benefits of tourism expectations that visit in the first place and are considerably beneficial for society without destroying the qualities. The other benefit that Geotourism for society accompanies maybe is more important and of value. That is superiority and pride which the society achieves after recognizing the valuable inheritance and following that is the responsibility that pictures these events in the eyes of visitors.

Iran has god-gifted valuable treasures, antecedent history and a cultural civilization that were always considered by visitors. Our country with different and various nature and climate is a small continent with numerous visitors. Nowadays, in a competitive world, various countries do their best to present their tourism attractiveness to improve their economical situation. Undoubtedly, our countries can do its best to improve the economical situation with hundreds of attractive and visiting places and also with this god-gifted wealth and keep irrevocable wealth like petroleum, gas and mines for more important usages.

Because of having unique geological shapes, Iran has been investigated for many years all over the world, and has also been called "the heaven of the geologist" and "1.5 million square kilometers museum of the geologists". The first attraction of Iran which is considered by the geotourists is its vast-spread geological phenomenon (Amrikazemi and Mehrpooya [1]).

Wetlands are the most biological spaces in the world because of having various unique biologics, several tourism recreation importance, innumerable scientific, investigation values, etc. They also have special situation in the international environmental protection system and biotravel accumulations (Papoliyazdi and Saqaei [9]).

The Gavkhoni Wetland, the ninth international wetland in Iran, with 47600 hectares extant in 145 kilometers is located in south-east part of Esfahan. This wetland is located between $32^{\circ}$ latitude, $22^{\circ}$ north minutes and $32^{\circ}, 15^{\circ}$ north minutes and $52^{\circ}$ east, $59^{\circ}$ minutes longitude Noori [8]. 
This wetland is natural, interior, free and has salt water which is settled in the list of Ramsar Convention with ZIR.18 code in 1975. The Gavkhoni Wetland is one of the most unique and rarest wetlands in the world because of having special geographical natural and habitat conditions and also ecological, biological and hydraulic factors, which is scientifically so important for researchers (Najari [7]). Geotourism pays attention to this area because of its old residence with a wealthy culture.

Considering the mentioned matters and the importance of the potentialities and limitations of the Gavkhoni Wetland, it can affect the planning of the sustainable tourism and its problems in this area. The authors try to introduce both the geotourists investments of the Gavkhoni Wetland and to investigate its strengths, weaknesses, opportunities and threats from the perspective of professors, students, geologists and visitors. Finally, according to these ideas and points, each interior and exterior factor which affects Geotourism of the Gavkhoni Wetland is assessed and evaluated based on the SWOT model.

\section{Discussion}

The strategic planning and evolution is one of the geographical science subjects which have been used recently. Strategic planning tries to evaluate all dimensions of the projects and plans in order to select the best and the most strategic decision. Indeed, this planning is a systematic way in order to make decisions and to carry out activities for forming, guiding and achieving its usage and results (Moradimasihi [6]).

Strategic management is a process for analyzing and recognizing the interior environment (strengths and weaknesses points) and the exterior environment (opportunities and threats points) of the systems. Besides, using this strategic management, the systems are established in their strategic way and strategies are created to achieve their aims (Harison and Karoon [3]).

Experience has shown that wherever tourism develops accidentally and without planning and strategy, several habitat and social problems emerge and in the long-term its problems become more than its usages (Ranjbarian and Zahedi [10]).

\section{The effective interior factors on the Gavkhoni Wetland Geotourism}

\subsection{Geological investments of the Gavkhoni Wetland}

Considering the tectonic situation, the Gavkhoni Wetland is created because of the subsidence (Darvishzadeh [2]). Educational/scientific tourism pays attention to this area for many reasons such as: placing in the Sirjan-Sanandaj geological zone, having a set of various sediments, emergence (genesis) of the numerous phases of the mountain, desert and volcanic stones (Fig. 1). This area can become a geologic geopark for studying and investigating for the researchers and students about the science of the earth and holding scientific tours. 


\subsubsection{Geomorphologic investments of the Gavkhoni Wetland}

The Gavkhoni Wetland area attracts the fans of Desert tourism, Sport tourism, Ecotourism and Health tourism because of having vast geomorphologic phenomena such as watery, wind and evaporative phenomena (Fig. 2).

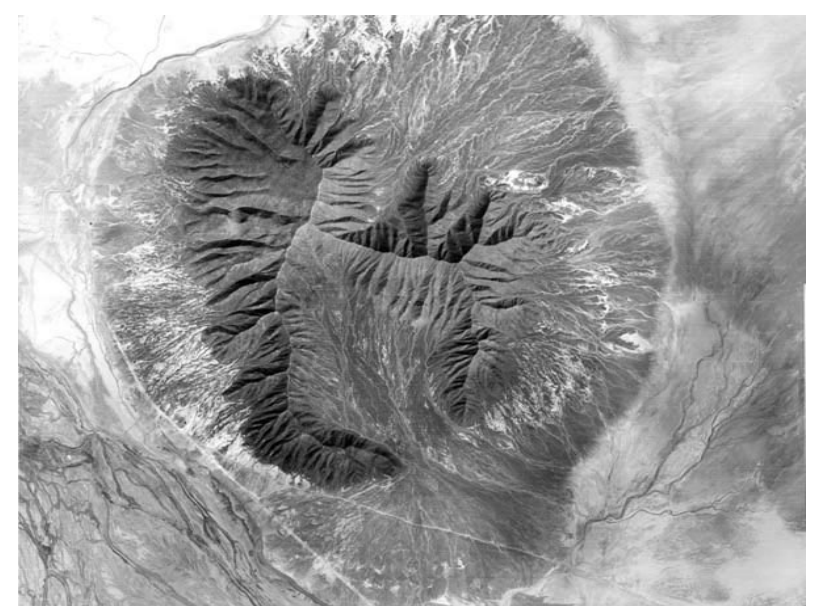

Figure 1: The black mountain that melted substances become cooled in the shape of a horse-shoe.

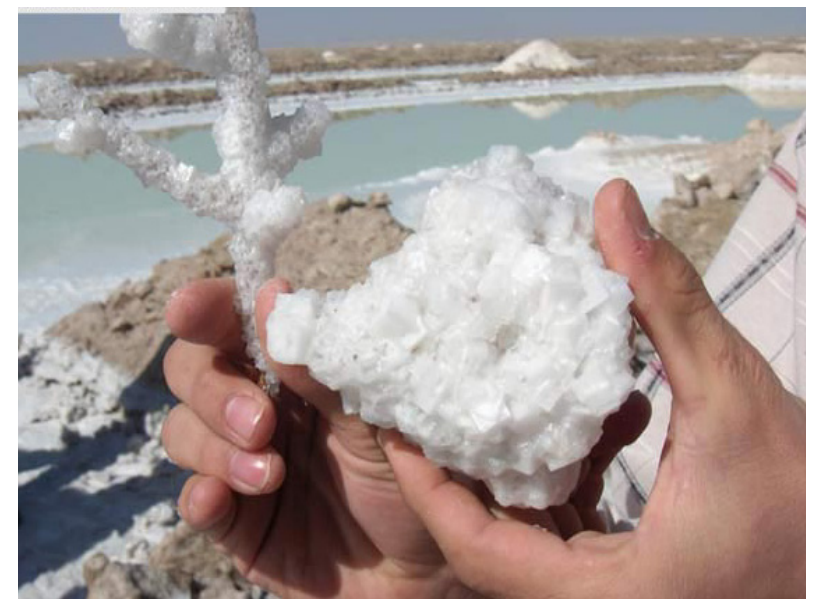

Figure 2: $\quad$ Salt mine in the south side of the Gavkhoni Wetland.

About the Desert, we can point to the usage of geotourist capabilities of the windy sands in the west side of the Gavkhoni Wetland, holding the seminar about the sand painted and Art tourism, visiting salty pelygon, salt mine and also visiting different shapes of compressed sand like citadels, sandy hills, seif, barkhan, nebeka, etc. 


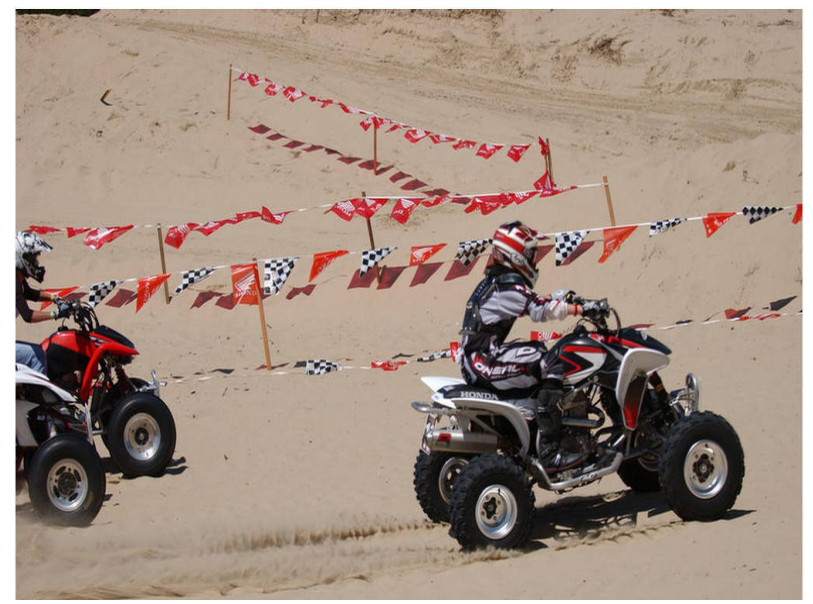

Figure 3: Bike riding in the western part of Gavkhoni wetland.

Regarding Sport tourism, it can point to the usage of geotourist capabilities in order to establish the motorcycling lands, to flying with a glider, paraglider and kite (Fig. 3).

Also, regarding Ecotourism, visiting the various geomorphic shapes like Zayanderood Delta, Shakh Kenar waterfall, river and lake teras and visiting the Karsetik springs and Artezin wells in this area are mentioned.

Finally, about Health tourism, we can mention the usage of the curative properties of the sands and calm, silent environment of the salt desert for resting and relaxing, the black mud of the Gavkhoni Wetland and the salt in this area. In order to achieve this aim, the authors advise the establishment of rooms for salt therapy near the borders of the Khara mine.

\subsection{Climatic investments of the Gavkhoni Wetland}

Since the Gavkhoni Wetland is located in the desert area of Iran, desert tourism is considered more. The existence of the annually average of sunny days (268/5 hours), is cause that this area is proper for the usage of solar generators (Iran Metrological organization [4]). This matter also accounts for the geotourist capabilities of this area for using renewal energy sources. Besides, the starry nights of the desert are appropriate for observing and studying for the astronomy fans.

To take advantage of the windy climate parameter in the desert which blows all the year on each side, in order to establish watching bases for observing the wind flows and movement of the sands.

\subsection{Herbaceous investments of the Gavkhoni Wetland}

Botanists can take advantage of the 50 species of plants which are classified in 12 families and 54 kinds of Najari [7]. One of the important issues about this 


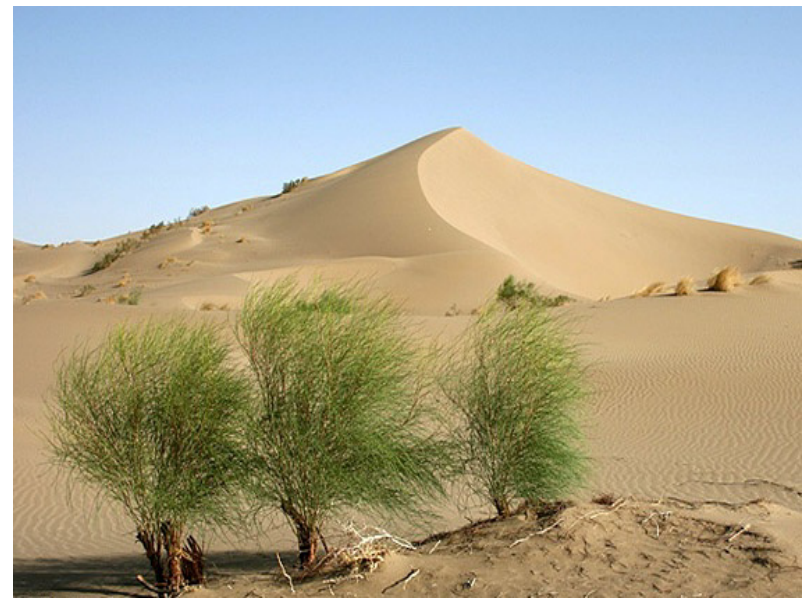

Figure 4: The Taq coverage over the western part of Gavkhoni wetland.

area is the existence of the salty kinds such as Gas and Taq which not only attract the salt of the soil but also prevent the spreading of the desert (Fig. 4). Also, we can point to the geotourist capabilities of the plant covering "Rush" for preparing handicrafts such as rush, mat, basket. It should be mentioned that we can enterprise for handy planting and reproduction for avoiding the destruction of rushes near the wetland.

\subsection{Animal investments of the Gavkhoni Wetland}

The International Gavkhoni Wetland counts as the most important habitat of animals in the central plateau of Iran. One of the geotourist capabilities in this area is the existence of various species of amphibian, creeps, mammals, native and immigrant birds which immigrate to this area each year because of cold weather (Moeineian [5]). We can take advantage of this property for bird watching via strong telescopes which are located in the black mountain. Although, in recent years we have observed the reduction of these species for many reasons such as drought and pollution, but with solving these problems, the wetland will experience its golden days again.

\subsection{Cultural-historical investments of the Gavkhoni Wetland area}

Because of possessing ancient villages and a wealthy culture, the Gavkhoni Wetland is figured as a powerful pole of Geotourism. There are historical attractions such as old mosques, bridges and historical bands, reservoirs, wind wards, caravansaries, dovecotes and historical village "Qahi" which have several camel houses and historical houses.

This area is the center of Historical tourism, Art tourism, Cultural tourism, and Rural tourism for many reasons such as traditional architecture, castle 
residences like "Qoortan Castle" which is the biggest bricked and mud building after the "Bam citadel" in Iran, unique handicrafts like karbafi, the unique clothing of the women of Varzaneh (white veil), Dari dialect of the local people, and attractive customs like Zar-o-Zar Khak customs in Qoortan, Erpa and Barat in Varzaneh.

\section{The weaknesses of Gavkhoni Wetland Geotourism}

Despite having several various geotourists investments the Gavkhoni Wetland has cannot attract interior and exterior tourists because of many reasons, some of which are gathered below:

1. Undetermined and unconfirmed aims and policies of the tourism industry;

2. Dispersion of the area and the long distance between the tourism places which is caused the limitation plan and organization for attracting the tourists in this area;

3. Low investment by the private part in this area;

4. Lack of enough effort by the tourism designer and planner for introducing this area in Iran;

5. Lack of enough budget for executing tourism projects and research;

6. Lack of correct culture and insight about tourism attraction by the staff and planners;

7. Lack of appropriate residential facilities and hospitalities in urban and rural areas according to the tourists' requests;

8. Inadequacy of trained experts and leaders in this area;

9. Lack of rebuilding, renovating and protecting Geotourism investment in this area.

It should be mentioned that the above items, weakness points, can change to golden opportunities with proper planning managing in the long term and attract a lot of tourists to this area.

\section{Analysis of the points of strength, weakness, opportunities and threats of Geotourism of the Gavkhoni Wetland (SWOT)}

As seen in Table 1, in the Gavkhoni Wetland and its neighboring area, there are 16 internal strengths against 12 internal weakness points, and 5 external opportunities against 8 external threats. In total, there are 21 strength points and opportunities as merits and 20 weaknesses and threats points as a limitation against the development of Geotourism of the Gavkhoni Wetland. However, we will have an international and national Geotourism pole if we decrease the internal and external weakness points and take advantage of the potentials and strengths points. 
Table 1: $\quad$ SWOT (the main effective factors) matrix on Geotourism of the Gavkhoni Wetland.

\begin{tabular}{|c|c|}
\hline Internal & External \\
\hline Strengths(S) & Opportunities(O) \\
\hline $\begin{array}{l}\mathrm{S}_{1} \text { : The existence of the beautiful and } \\
\text { unique sights such as; the location of } \\
\text { The Gavkhoni Wetland in central } \\
\text { plateau of Iran, Black mountain, } \\
\text { Artezin wells, Karsetik springs, } \\
\mathrm{S}_{2} \text { : The existence of various and } \\
\text { excellent historical attractions, } \\
\text { customs, local dialect, special } \\
\text { clothing of the women ... } \\
\mathrm{S}_{3} \text { : Variety of the Geomorphologic } \\
\text { phenomenon; watery, windy and } \\
\text { evaporatory such as; sand dunes, } \\
\text { river and lake terraces, delta, salty } \\
\text { polygon and salty mine.... } \\
\mathrm{S}_{4} \text { : Taking advantage of the variety of } \\
\text { geological structure of this area .... } \\
\mathrm{S}_{5} \text { : Taking advantage of the sport } \\
\text { potential of the sand dunes for flying } \\
\text { and training flight with glider and } \\
\text { paraglider, sand climbing and camel } \\
\text { riding } \\
\mathrm{S}_{6} \text { : Taking advantage of the sand } \\
\text { therapy in the west borders and salt } \\
\text { therapy in the south-west of the } \\
\text { Gavkhoni Wetland for establishing } \\
\text { rooms for the salt therapy and making } \\
\text { salty lamp-shades, salty candlestick, } \\
\text { salty massage stones, salty pipe... } \\
\mathrm{S}_{7} \text { : Taking advantage of the } \\
\text { Geotourism potential of the sand } \\
\text { dunes for holding sand-painted } \\
\text { congresses and making sand } \\
\text { sculpture } \\
\mathrm{S}_{8} \text { : Taking advantage of the desert } \\
\text { climatic parameters for watching the } \\
\text { smooth and starry sky at night, using } \\
\text { the solar generators with regard to the } \\
\text { high number of the sunny hours, } \\
\text { making watching rooms for the study } \\
\text { of the sand and wind movements in } \\
\text { the desert }\end{array}$ & $\begin{array}{l}\mathrm{O}_{1} \text { : Multidirectional Geotourism } \\
\text { insight which covers all sides of } \\
\text { tourism more than the unidirectional } \\
\text { tourism of the neighboring area } \\
\mathrm{O}_{2} \text { : Placing a crowded city (Esfahan), } \\
\text { Varzaneh and other urban and rural } \\
\text { centers next to the Gavkhoni Wetland } \\
\mathrm{O}_{3} \text { : Paying more attention to the } \\
\text { planning and investment in } \\
\text { Geotourism part by the government } \\
\mathrm{O}_{4} \text { : Rising the motivation of the } \\
\text { private sector on the investment in } \\
\text { this area } \\
\mathrm{O}_{5} \text { : Rising the motivation for holding } \\
\text { national and regional tours and } \\
\text { travels }\end{array}$ \\
\hline
\end{tabular}


Table 1: Continued.

\begin{tabular}{|c|c|}
\hline Internal & External \\
\hline Strengths(S) & Opportunities(O) \\
\hline $\begin{array}{l}\mathrm{S}_{9} \text { : The high level of the knowledge, } \\
\text { culture and cooperation sense of the } \\
\text { local people in this area especially in } \\
\text { Varzaneh city } \\
\mathrm{S}_{10} \text { : The creation of pride and } \\
\text { superiority sense in the local people } \\
\text { after introducing geotourists } \\
\text { investments of their area } \\
\mathrm{S}_{11} \text { : Preparing for Geotourism } \\
\text { investment and planning and taking } \\
\text { advantage of the natural and } \\
\text { humanistic attractions to the world } \\
\text { Geotourism market } \\
\mathrm{S}_{12} \text { : Powerful Geotourism facilities } \\
\text { and potentials for the attraction of the } \\
\text { tourists in all parts especially in } \\
\text { Geotourism } \\
\mathrm{S}_{13} \text { : Taking advantage of the animal } \\
\text { investments of the Gavkhoni Wetland } \\
\text { especially the immigrant birds in the } \\
\text { Bird watching part } \\
\mathrm{S}_{14} \text { : Taking advantage of the plant } \\
\text { covering, rush, for Booria Bafi } \\
\text { industry considering the carminative } \\
\text { property of rush } \\
\mathrm{S}_{15} \text { : Taking advantage of the salt } \\
\text { mines and salt waters for establishing } \\
\text { Aquaculture and training Artemia } \\
\mathrm{S}_{16} \text { : Taking advantage of the } \\
\text { calmness and silence of the desert for } \\
\text { relaxing }\end{array}$ & $\begin{array}{l}\mathrm{O}_{2} \text { : Placing a crowded city (Esfahan), } \\
\text { Varzaneh and other urban and rural } \\
\text { centers next to the Gavkhoni Wetland } \\
\mathrm{O}_{3} \text { : Paying more attention to the } \\
\text { planning and investment in } \\
\text { Geotourism part by the government } \\
\mathrm{O}_{4} \text { : Rising the motivation of the } \\
\text { private sector on the investment in } \\
\text { this area } \\
\mathrm{O}_{5} \text { : Rising the motivation for holding } \\
\text { national and regional tours and } \\
\text { travels }\end{array}$ \\
\hline Weaknesses $(W)$ & Threats (T) \\
\hline $\begin{array}{l}\mathrm{W}_{1} \text { : Lack of appropriate residential } \\
\text { facilities and hospitalities according } \\
\text { to the tourists' requests in the urban } \\
\text { and rural areas. } \\
\mathrm{W}_{2} \text { : Lack of unified planning and } \\
\text { policies because of the dispersion of } \\
\text { tourism areas from each other. } \\
\mathrm{W}_{3} \text { : Low investment in the } \\
\text { Geotourism part in this area }\end{array}$ & $\begin{array}{l}\mathrm{T}_{1} \text { : Entering the rural, urban and } \\
\text { industrial population, drained salty } \\
\text { lands and transferring to Zayandeh } \\
\text { Rood directly and indirectly and as a } \\
\text { result endangering the ecosystems of } \\
\text { the wetland and wiping out the } \\
\text { animal and plant species } \\
\mathrm{T}_{2} \text { : Decreasing the entrance water } \\
\text { from Zayandeh Rood to the wetland }\end{array}$ \\
\hline
\end{tabular}


Table 1: Continued.

\begin{tabular}{|c|c|}
\hline Weaknesses (W) & Threats (T) \\
\hline $\begin{array}{l}\mathrm{W}_{4} \text { : Lack of rebuilding, renovating } \\
\text { and protecting the Geotourism } \\
\text { investment in this area } \\
\mathrm{W}_{5} \text { : Inadequacy of trained experts } \\
\text { and leaders in this area } \\
\mathrm{W}_{6} \text { : Lack of acceptance of the local } \\
\text { clothing, dialect and handicrafts by } \\
\text { the young generation } \\
\mathrm{W}_{7} \text { : Lack of enough budget for the } \\
\text { tourism project in this area } \\
\mathrm{W}_{8} \text { : Destruction of the traditional } \\
\text { architecture of the area and replacing } \\
\text { it by the same modern structure } \\
\mathrm{W}_{9} \text { : Inappropriate environmental } \\
\text { infrastructures such as urban and } \\
\text { rural sewage system } \\
\mathrm{W}_{10} \text { : The existence of the contrast } \\
\text { and difference between the culture of } \\
\text { the local people and tourists } \\
\mathrm{W}_{11} \text { : Desert genesis and development } \\
\mathrm{W}_{12} \text { : High evaporation because of the } \\
\text { desert situation and hot and dry } \\
\text { weather of this area. }\end{array}$ & $\begin{array}{l}\text { and not providing the utilized water } \\
\text { for the wetland } \\
\mathrm{T}_{3} \text { : Establishing the connecting road } \\
\text { between Varzaneh and Nodoushan } \\
\text { near the wetland against the Ramsar } \\
\text { agreement } \\
\mathrm{T}_{4} \text { : The extension of the traditional } \\
\text { and local culture such as dialect, } \\
\text { customs, architecture and residence } \\
\text { because of coming large number of } \\
\text { the tourists to this area } \\
\mathrm{T}_{5} \text { : Cultural incompatibility among } \\
\text { tourisms and local people in this area } \\
\mathrm{T}_{6} \text { : Price increase of the lands, bourse } \\
\text { and subsequently price } \\
\mathrm{T}_{7} \text { : Destructing the animal and plant } \\
\text { covering in this area because of the } \\
\text { illegal usage and unlawful haunting } \\
\mathrm{T} 8 \text { : The existence of the large } \\
\text { number of people in this area because } \\
\text { of disobeying of tourism management } \\
\text { principles }\end{array}$ \\
\hline
\end{tabular}

\section{Conclusion}

In this study, according to the data which are obtained from the responses of the professors of the geography and geology, students and tourists analyzed by this model, the most important strength point of the Geotourism of the Gavkhoni Wetland the existence of the numerous and excellent historical attractions and the most important weakness is Lack of appropriate residential facilitations and hospitalities. Although, this area has potential and powerful geotourists investments but it faces with management weak points. We have a national and even international Geotourism pole if these weaknesses wipes out.

After analyzing the data by this model, the most important strength point of the Geotourism of the Gavkhoni Wetland is multidirectional Geotourism insight which covers all sides of it and the most important weakness is entering the rural, urban and industrial population, drained salty lands. Therefore, its population should be decreased and also its required water should be prepared by the proper management. 


\section{References}

[1] Amrikazemi, A, Mehrpooya, A, "Global Geotourism", chapter 5, Geotourism resources of Iran”, Elsevier, 290, 2006.

[2] Darvishzadeh, A, "Iran geology", Amir Kabir Pub, 902, 1991.

[3] Harison. G, Karoon, G, "Strategic Management", Translator: Qasemi. Behrooz, Heyat Pub, 289, 2003.

[4] Iran Metrological organization, http://www.weather.ir,n.d.

[5] Moeineian, $\mathrm{H}$ "Investigation of the Ecology and Quality of the Zayandeh Rood River", MA Thesis, Islamic Azad Ahvaz University, 2000.

[6] Moradimasihi, V, "Strategic planning in huge cities", Urban Planning and Processing Pub, 252, 2002.

[7] Najari, H, "Gavkhoni international Wetland", Environmental Protection Agency Pub, 164, 2003.

[8] Noori, H, "Valued study of Isfahan tourism centers (The Gavkhoni Wetland)", Isfahan culture, 15 number, 2000.

[9] Papoliyazdi, M, Saqaei, M. "Tourism (characters and concepts)", Samt Publication, 284, 2006.

[10] Ranjbarian .B, Zahedi. M, "Tourism Planning at the Regional and National Level", Isfahan Jahad Daneshgahi, 1999.

[11] Sharifzadeh, A, MoradNejad, H z, "Sustainable Development and Rural Tourism", Jahad social economical monthly magazine, Tir and Khordad, 2002.

[12] Tourtellot, J, http://www.nationalgeographic.com/travel/sustainable/, n.d. 